\title{
Reminder dengan Short Message Service (SMS) Untuk Meningkatkan Kepatuhan Kunjungan K4 dan Kemampuan Deteksi Dini Tanda Bahaya Ibu Hamil Trimester III
}

\author{
Dewi Afidatul Ummah ${ }^{1}$, Gita Kostania ${ }^{2 *}$, Rosalinna $^{3}$ \\ ${ }^{1,3}$ Jurusan Kebidanan, Poltekkes Kemenkes Surakarta, ${ }^{2}$ Jurusan Kebidanan, Poltekkes Kemenkes Malang \\ *Email: kostania.gita@gmail.com
}

\begin{abstract}
Background: Low $K 4$ rate coverage and management of complications in pregnancy is a problem in Klaten, caused by lack of information and motivation in antenatal care. Short Message Service (SMS) can be used as a support intervention to increase information. This research aims to determine effects of SMS toward $K 4$ compliance and screening danger sign ability among third trimester pregnancy in Wedi Public Health Center. Methods: type of research is a quasy experimental with post-test only non-equivalent control group. The sampling technique used Quota sampling, obtain 52 respondents in the third trimester of pregnancy. Data analysis techniques used Mann Whitney and Chi Square with a significance level of 0.05. Result: K4 compliance of pregnancy could be classified as disobedient of 59,6\% and screening danger sign ability among third trimester pregnancy is considered relatively of 53.8\%. SMS had a strong impact toward K4 compliance with a $p$ value =0,002 ( $p<0,05)$. SMS also affected screening danger sign ability among third trimester pregnancy with a $p$ value $=0.001$ ( $p<0.05)$. Conclusion: There is significant effects between SMS toward K4 compliance and screening danger sign ability among third trimester pregnancy in Wedi Pubic Health Center, Klaten Regency.
\end{abstract}

Keywords: $k 4$ compliance, screening danger sign ability among third trimester pregnancy, short message service (SMS)

\section{PENDAHULUAN}

Kehamilan merupakan suatu hal yang fisiologis dan alamiah, tetapi dalam prosesnya tidak selamanya berjalan normal, terkadang diiringi oleh gangguan yang dapat menyebabkan kematian pada ibu atau kematian pada bayi. Angka Kematian ibu pada tahun 2016 dan 2017 mengalami penurunan, namun hal ini masih jauh dari pencapaian target sasaran Sustainable Development Goals (SDGs) pada tahun 2030 (Ermalena, 2017). Kebijakan yang dilakukan oleh pemerintah sebagai upaya memperbaiki kesehatan ibu salah satunya yaitu pelayanan kesehatan ibu hamil.

Kebijakan program pelayanan Antenatal menetapkan frekuensi kunjungan antenatal sebaiknya dilakukan paling sedikit 4 kali selama kehamilan, dengan ketentuan waktu minimal 1 kali sebelum minggu ke $16(\mathrm{KI})$, minimal 1 kali antara minggu ke 24 dan 28, dan minimal 2 kali antara minggu 30-32 dan antara minggu 36-38 (K3 dan K4), selain itu, setidaknya melakukan 1 kali pemeriksaan ke dokter untuk deteksi kelainan medis (Kementerian Kesehatan Republik Indonesia, 2016). Pada tahun 2017 cakupan K4 di kabupaten Klaten sebanyak 92,9\%, sedangkan hasil dari telaah dokumen laporan tahunan cakupan K4 di Puskesmas Wedi pada tahun 2018 sebanyak $84,53 \%$. Sedangkan penanganan komplikasi 101,6\%. Rendahnya cakupan dimungkinkan karena kurangnya informasi dan tidak adanya dorongan dalam memeriksakan kehamilan.

Short Message Service (SMS) dapat digunakan sebagai intervensi pendukung peningkatan informasi, karena memudahkan tenaga kesehatan 
mengirimkan informasi dan dukungan kepada ibu hamil atau memudahkan ibu hamil untuk mengakses informasi dan dukungan kepada tenaga kesehatan secara mandiri (Wahyuni, 2017). SMS memiliki kelebihan diantaranya yaitu efisien, biaya lebih murah dibandingkan telepon, mudah digunakan oleh semua kalangan, dan dapat digunakan dalam jaringan $2 \mathrm{G}$ sehingga memiliki kemampuan untuk menyebarluaskan informasi kesehatan kedaerah sulit dan terpencil (Abdiansyah, 2009; Kurnia \& Ibrahim, 2015).

Berdasarkan uraian diatas, maka peneliti berkeinginan untuk melakukan penelitian tentang pengaruh SMS terhadap kepatuhan K4 dan kemampuan deteksi tanda bahaya pada ibu hamil trimester III di wilayah Puskesmas Wedi. Hasil literature review peneliti tidak ada penelitian terkait penggunaan SMS untuk reminder K4. Penelitian ini bertujuan ntuk mengetahui pengaruh Short Message Service terhadap kepatuhan K4 dan kemampuan deteksi dini tanda bahaya pada ibu hamil trimester III di Puskesmas Wedi, Klaten.

\section{METODE PENELITIAN}

Jenis penelitian ini yaitu quasi eksperimental dengan post test only nonequivalent control group design, yaitu penelitian yang menggunakan satu kelompok eksperimen dan satu kelompok kontrol yang tidak dipilih secara random, kemudian setelah diberikan intervensi kedua kelompok diberikan tes akhir (Sugiyono, 2016). Intervensi pada kelompok eksperimen yaitu berupa pemberian Short Message Service selama 6 minggu.Penelitian ini dilaksanakan pada bulan Desember 2018 sampai dengan Mei 2019 di wilayah Puskesmas Wedi, Klaten.
Populasi target adalah seluruh ibu hamil di wilayah Puskesmas Wedi, Klaten. Sedangkan populasi aktual adalah semua ibu hamil trimester III di wilayah Puskesmas Wedi, Klaten, yang meliputi 12 desa, terdapat 114 ibu hamil. Teknik pengambilan sampel pada penelitian ini adalah Quota Sampling yaitu pengambilan sampel dengan menentukan ciri ciri tertentu sampai jumlah kuota yang diinginkan (Hidayat, 2010). Pada penelitian ini jumlah sampel yang memenuhi kriteria inklusi 52 ibu dan tidak memenuhi kriteria inklusi 48 ibu. Kriteria inklusi terdiri dari Ibu hamil umur kehamilan 28- 32 minggu, tidak ada resiko tinggi atau komplikasi, memiliki handphone dan nomor aktif, bersedia menjadi responden, dapat mendengar, menulis, membaca, dan berkomunikasi dengan lancar.

Kelompok eksperimen terdiri dari 26 ibu hamil dengan intervensi pemberian Short Message Service dengan GiliSMS® yang diberikan 3 kali yang berisi pengingat untuk melakukan kunjungan K4, pemberian SMS 18 kali tentang deteksi dini tanda bahaya pada kehamilan trimester III yang dilakukan bertahap dan dan diberikan pendidikan kesehatan mengenai tanda bahaya kehamilan trimester III pada saat kelas ibu hamil. Kelompok kontrol terdiri dari 26 ibu hamil, pada kelompok ini hanya diberikan pendidikan kesehatan mengenai tanda bahaya kehamilan trimester III pada saat kelas ibu hamil. Instrumen yang digunakan dalam penelitian ini adalah lembar observasi dan lembar kuisioner. Lembar observasi bertujuan untuk mengobservasi tingkat kepatuhan antenatal care pada ibu hamil trimester III dan untuk mengukur kemampuan ibu dalam deteksi tanda bahaya digunakan 
modifikasi kuesioner dari penelitian Sarah Ardilah tahun 2015 di Puskesmas Medan Deli yang berjumlah 10 butir soal (Ardillah, Sanusi, \& Fitria, 2015). Soal kuisioner telah dilakukan uji validitas dan reliabilitas pada bulan Maret 2019, uji tersebut dilakukan pada 20 orang ibu hamil trimester III di Wilayah Puskesmas Klaten Selatan. Hasil uji kuisoner dinyatakan valid dan reliabel. Teknik analisis data menggunakan Mann Whitney dan Chi Square dengan taraf siginfikasi 0,05 .

\section{HASIL PENELITIAN}

Berikut adalah hasil karakteristik responden dari penelitian ini:

Tabel 1. Data Karakteristik Responden

\begin{tabular}{llcc}
\hline & Karakteristik & $\begin{array}{c}\text { Jumlah } \\
\text { (Orang) }\end{array}$ & $\begin{array}{c}\text { Presentase } \\
(\boldsymbol{\%})\end{array}$ \\
\hline Umur & < 20 tahun & 1 & 1,9 \\
& 20- 35 tahun & 45 & 86,5 \\
\multirow{5}{*}{ Pekerjaan } & $>$ 35 tahun & 6 & 11,5 \\
& Tidak Bekerja & 24 & 46,2 \\
& Bekerja & 28 & 53,8 \\
\multirow{3}{*}{ Pendidikan } & Tidak Tamat SD & 1 & 1,9 \\
& Tamat SD & 2 & 3,8 \\
& Tamat SMP & 18 & 34,6 \\
& Tamat SMA & 27 & 51,9 \\
& Perguruan Tinggi/ Akademi & 4 & 7,7 \\
\hline
\end{tabular}

Karakteristik responden berdasarkan umur di wilayah Puskesmas Wedi Klaten sebagian besar responden umur 20-35 tahun sebanyak 45 orang $(86,5 \%)$. Karakteristik responden berdasarkan pekerjaan di wilayah Puskesmas Wedi
Klaten diketahui bahwa sebagian besar responden bekerja sebanyak 28 orang atau 53,6\% Pendidikan Karakteristik responden dapat diketahui sebagian besar responden berpendidikan SMA yaitu sebanyak 27 orang atau $51,9 \%$

Tabel 2. Distribusi Frekuensi Berdasarkan Kepatuhan Antenatal Care di Puskesmas Wedi

\begin{tabular}{ccc}
\hline Kriteria & N & \% \\
\hline Patuh & 21 & 40,4 \\
Tidak Patuh & 31 & 59,6 \\
\hline Total & $\mathbf{5 2}$ & $\mathbf{1 0 0 , 0}$ \\
\hline
\end{tabular}

Berdasarkan tabel 2 diatas dapat diketahui bahwa Ibu hamil yang patuh dalam memeriksakan kehamilanya yang sejumlah 21 orang $(40,4 \%)$ dan Ibu hamil tidak patuh dalam melakukan pemeriksaan kehamilan sejumlah 31 orang $(59,6 \%)$. 
Tabel 3. Distribusi Frekuensi Berdasarkan Kemampuan Deteksi Dini Tanda Bahaya Kehamilan di Puskesmas Wedi

\begin{tabular}{crr}
\hline Kriteria & N & \% \\
\hline Baik & 23 & 44,2 \\
Cukup & 28 & 53,8 \\
Kurang & 1 & 1,9 \\
\hline Total & $\mathbf{5 2}$ & $\mathbf{1 0 0 , 0}$
\end{tabular}

Berdasarkan tabel 3 diatas dapat diketahui bahwa kemampuan deteksi dini tanda bahaya kehamilan trimester III di Puskesmas Wedi yaitu cukup. Hasil kemampuan deteksi dini tanda bahaya pada ibu hamil di Puskesmas Wedi yaitu baik 23 orang $(44,2 \%)$, cukup 28 orang $(53,8 \%)$, dan kurang 1 orang $(1,9 \%)$.

Tabel 4. Hasil Uji Statistik Pengaruh Short Message Service terhadap Kepatuhan Antenatal Care dengan Chi Square

\begin{tabular}{|c|c|c|c|c|c|}
\hline \multirow[b]{2}{*}{ Kelompok } & \multicolumn{2}{|c|}{ Kepatuhan K4 } & \multirow[b]{2}{*}{ Total } & \multirow{2}{*}{$x^{2}$} & \multirow{2}{*}{$\underset{\text { value }}{\rho}$} \\
\hline & Patuh & Tidak Patuh & & & \\
\hline Intervensi & 16 & 10 & 26 & \multirow{3}{*}{$9,665^{\mathrm{a}}$} & \multirow{3}{*}{0,002} \\
\hline Kontrol & 5 & 21 & 26 & & \\
\hline Total & 21 & 31 & 52 & & \\
\hline
\end{tabular}

Pada tabel 3 diketahui bahwa ada perbedaan tingkat kepatuhan pada kelompok intervensi dan kontrol. Hasil uji chi square menunjukkan nilai $\rho$ value sebesar 0,002, dimana $\rho<0,05$, maka ada pengaruh Short Message Service terhadap kepatuhan antenatal care pada ibu hamil trimester III.

Tabel 5. Hasil Uji Statistik Pengaruh Short Message Service terhadap Kemampuan Deteksi Dini Tanda Bahaya Ibu Hamil Trimester III dengan Mann Whitney

\begin{tabular}{lccccc}
\hline Kemampuan & Kelompok & N & Mean & Ranks & p value \\
\cline { 2 - 6 } $\begin{array}{l}\text { Deteksi Dini } \\
\text { Tanda Bahaya }\end{array}$ & Intervensi & 26 & 34,13 & 887,50 & \\
TM III & Kontrol & 26 & 18,87 & 490,50 & 0,001 \\
\hline \multicolumn{1}{c}{ Total } & & $\mathbf{5 2}$ & & & \\
\hline
\end{tabular}

Berdasarkan tabel 5 diketahui bahwa ada perbedaan tingkat kemampuan deteksi dini tanda bahaya ibu hamil trimester III kelompok intervensi dan kontrol sebesar 15,26. Hasil uji statistik
Mann Whitney menunjukkan nilai $\rho$ value sama dengan 0,001 dimana $\rho<0,05$, maka dapat disimpulkan ada pengaruh Short Message Service terhadap kemampuan deteksi dini tanda bahaya ibu hamil trimester II. 


\section{PEMBAHASAN}

Berdasarkan hasil penelitian pada tabel 1 karakteristik responden berdasarkan umur di wilayah Puskesmas Wedi Klaten sebagian besar responden umur 20-35 tahun sebanyak 45 orang $(86,5 \%)$. Menurut penelitian, kurun waktu reproduksi sehat adalah 20- 35 tahun dan resiko kehamilan dan persalinan baik bagi ibu maupun bagi anak lebih tinggi pada usia kurang dari 20 tahun, paling rendah pada usia 20-35 tahun dan meningkat lagi secara tajam lebih dari 35 tahun (Andaruni, Pamungkas, \& Lestari, 2017). Karakteristik responden berdasarkan pekerjaan di wilayah Puskesmas Wedi Klaten diketahui bahwa sebagian besar responden bekerja sebanyak 28 orang atau $(53,6 \%)$. Hal ini didukung oleh penelitian Andaruni (2017) bahwa pekerjaan sesorang akan dapat menunjukkan tingkat sosial ekonomi yang dapat mempengaruhi kemampuan dalam menyerap informasi.

Karakteristik responden dapat diketahui sebagian besar responden berpendidikan SMA yaitu sebanyak 27 orang atau $(51,9 \%)$. Berdasarkan penelitian Andaruni menyatakan bahwa semakin tinggi tingkat pendidikan seseorang maka makin mudah menerima informasi sehingga makin banyak pengetahuan yang dimiliki, sebaliknya pendidikan yang kurang akan menghambat perkembangan seseorang terhadap nilai-nilai yang baru diperkenalkan (Andaruni et al., 2017). Selain itu menurut penelitian Budiman dengan judul "Hubungan Tingkat Pendidikan, Pekerjaan, Status Ekonomi dengan Paritas di Puskesmas Bahu Manado" menjelaskan bahwa semakin tinggi tingkat pendidikan, maka kemampuan ibu dalam berpikir lebih rasional dan sangat mempengaruhi bagaimana seseorang untuk bertindak dan mencari penyebab, serta solusi dalam hidupnya (Elhaeart, Kundre, \& Lolong, 2017).

Berdasarkan hasil penelitian pada tabel 2 diatas memperlihatkan tingkat kepatuhan ibu hamil di Puskesmas Wedi. Ibu hamil yang patuh dalam memeriksakan kehamilannya sejumlah 21 orang $(40,4 \%)$ dan ibu hamil yang tidak patuh dalam melakukan pemeriksaan kehamilan sejumlah 31 orang $(59,6 \%)$. Jumlah ibu hamil yang tidak patuh dalam memeriksakan kehamilan cukup besar, Menurut Pattipeilohy dalam penelitiannya melaporkan bahwa ada hubungan antara dukungan suami dengan kunjungan antenatal care di Puskesmas Rekas yang dibuktikan dengan nilai $\rho(0,021)<\alpha$ $(0,05)$ dan hasil ratio prevalence sebesar 6,364 , yang menunjukkan bahwa ibu yang mendapatkan dukungan suami berpeluang 6,364 kali melakukan pemeriksaaan antenatal care (Pattipeilohy, 2018).

Keluarga sebagai lingkungan yang terdekat dengan ibu hamil, dukungan dari suami dan keluarga memegang peranan penting dalam memengaruhi psikologi dan motivasi ibu dalam melakukan perilaku kesehatan. Dengan dukungan yang baik, maka ibu akan memperhatikan kesehatan diri dan janinya yaitu dengan memeriksakan secara rutin kehamilannya (Rachmawati, Puspitasari, \& Cania, 2017). Sikap petugas kesehatan di fasilitas kesehatan mempengaruhi frekuensi kunjungan antenatal care. Semakin baik sikap petugas kesehatan maka semakin sering ibu memeriksakan kehamilannya. Belum menetapnya petugas kesehatan yang ada di daerah juga dapat menurunkan akses ibu hamil untuk mendapatkan pelayanan kesehatan (Rachmawati et al., 2017). Media 
informasi dapat mencakup informasi mengenai pentingnya pelayanan antenatal care sehingga dapat meningkatkan pengetahuan dan motivasi ibu dalam melakukan kunjungan (Rachmawati et al., 2017).

Berdasarkan hasil penelitian pada tabel 3 diatas dapat diketahui bahwa kemampuan deteksi dini tanda bahaya kehamilan trimester III di Puskesmas Wedi yaitu cukup. Hasil kemampuan deteksi dini tanda bahaya pada ibu hamil di Puskesmas Wedi yaitu baik 23 orang $(44,2 \%)$, cukup 28 orang $(53,8 \%)$, dan kurang 1 orang $(1,9 \%)$. Hal ini dikarenakan adanya faktor predisposisi yaitu keterpaparan informasi, salah satunya informasi yang diberikan oleh tenaga kesehatan melalui Short Message Service. Pada kelompok intervensi, ibu hamil membaca dan membalas pesan yang diberikan oleh tenaga kesehatan. Selain informasi, ibu hamil juga mendapatkan pengingat untuk melakukan kunjungan $\mathrm{K} 4$ melalui SMS sehingga ada peningkatan kepatuhan dalam melakukan kunjungan K4.

Menurut penelitian Dewi, melaporkan bahwa ibu hamil yang terpapar informasi tentang tanda bahaya mampu melakukan deteksi dini dengan baik dibandingkan dengan ibu hamil yang tidak terpapar informasi tanda bahaya. Kemudahan untuk memperoleh suatu informasi akan mempercepat seseorang untuk memperoleh pengetahuan yang baru. Selain itu, pada penelitiannya, menunjukkan bahwa ibu hamil yang teratur melakukan pemeriksaan ANC kemampuan deteksi dininya lebih baik dibandingkan ibu hamil yang tidak teratur melakukan pemeriksaan ANC dengan Odds ratio (OR) sebesar 5,657 (Galuh et al., 2015).
Menurut Walyani, bahwa tujuan dari antenatal care salah diantaranya yaitu memantau kesehatan ibu dan janin, mempertahankan kesehatan fisik, mendeteksi secara dini adanya komplikasi. Apabila ibu hamil tidak melakukan pemeriksaan antenatal care berarti tidak dapat dilakukan deteksi dini sejak awal jika terdapat komplikasi atau kelainan kehamilan, dimana kondisi ini dapat mengakibatkan komplikasi pada saat hamil atau pada saat persalinan yang akan mengarah kepada kematian baik ibu maupun janin (Walyani, 2015).

Berdasarkan table 4 hasil uji statistik menujukkan hasil $(\rho$ value $=0,002)$, hal ini menunjukkan bahwa terdapat perbedaan kepatuhan ibu hamil dalam melakukan antenatal care antara kelompok intervensi dan kelompok kontrol. Hal ini sesuai dengan penelitian yang dilakukan oleh Lestari bahwa ibu hamil yang mendapatkan SMS reminder terdapat perbedaan yang bermakna dalam mengonsumsi tablet $\mathrm{Fe} \quad(\rho=0,009)$ (Lestari, 2015).

Short Messaging Service (SMS) sebagai media dalam menyampaikan informasi, diberikan secara kontinu dan berkesinambungan sehingga berpengaruh terhadap pengetahuan dan perilaku subjek penelitian. Media pada umumnya efektif untuk memberikan stimulasi untuk menuju pada tindakan yang nyata (Kusfriyadi, Hadi, \& Fuad, 2012). Menurut Theory Of Planned Behavior (TPB), jika seseorang menganggap perilaku yang disarankan sebagai sesuatu yang positif (sikap) dan berpikir bahwa orang terdekat menginginkan perilaku tersebut dijalankan (norma subjektif), orang tersebut merasakan kontrol terhadap perilaku (efikasi diri sendiri). Sehingga 
hal ini akan meningkatkan intensi untuk mengubah perilaku (Wahyuni, 2017).

Berdasarkan tabel 5 diketahui hasil uji statistik Mann Whitney menunjukkan nilai $\rho$ value sama dengan 0,001 , dimana $\rho$ $<0,05$. Hal ini menunjukkan bahwa ada perbedaan tingkat kemampuan deteksi dini tanda bahaya ibu hamil trimester III kelompok intervensi dan kontrol. Menurut penelitian Herlina bahwa pengetahuan merupakan faktor penting dalam terbentuknya perilaku. Informasi yang diterima dari SMS reminder oleh sasaran apabila sumber informasi menggunakan metode dan teknik tertentu dalam menambah jumlah informasi serta melakukannya secara berulang dapat menjadi stimulus, maka sasaran akan semakin mudah menerima pesan yang diberikan (Herlina, Sanjaya, \& Emilia, 2013).

Hasil dari penelitian ini juga sesuai dengan penelitian Dewi Afidatul Ummah dan Gita Kostania yang berjudul "Penggunaan Text Messaging Program untuk meningkatkan Kemampuan Ibu Hamil dalam Deteksi Dini Tanda Bahaya Kehamilan" hasil penelitian tersebut menunjukkan bahwa Text Messaging Program berpengaruh kuat terhadap kemampuan ibu hamil dalam deteksi dini tanda bahaya kehamilan dengan nilai $\mathrm{p}$ value $=0,001 \quad(\mathrm{p}<0,05)$. Hal ini dikarenakan Text Messaging Program dapat digunakan sebagai intervensi pendukung dalam meningkatkan informasi untuk ibu hamil (Ummah \& Kostania, 2019).

Penelitian di Argentina pemanfaatan media layanan pesan singkat kepada ibu hamil memperlihatkan bahwa layanan pesan singkat menyebabkan meningkatnya kehadiran ibu hamil di pelayanan kesehatan serta efektif dalam meningkatkan upaya promotif guna perubahan pengetahuan, sikap dan perilaku kesehatan. Layanan pesan singkat memiliki potensi untuk mempengaruhi perubahan perilaku karena kemampuan untuk menyebarluaskan informasi kesehatan, bahkan dapat mencapai populasi yang sulit dijangkau. Telepon seluler ini dapat menjadi pilihan yang sangat berguna untuk meningkatkan kemampuan ibu hamil (Cormick et al., 2012).

Dalam pelaksanaan penelitian ini, peneliti menggunakan aplikasi SMS (Gili SMS) yang didukung oleh GSM. Aplikasi ini memiliki kelebihan diantaranya yaitu efisien, biaya lebih murah dibandingkan telepon, dan memiliki kemampuan untuk menyebarluaskan informasi kesehatan kedaerah sulit dan terpencil, sedangkan kelemahan dari aplikasi ini yaitu menggunakan pulsa untuk mengirim text messaging dan membutuhkan komputer server yang harus selalu hidup dan sebuah modem untuk pengiriman SMS-nya (Herlina, 2018). Solusi alternatif untuk memperbaiki kelemahan tersebut yaitu menggunakan sosial media, karena sosial media seperti Whatsapp memiliki kelebihan mengirim pesan tanpa biaya SMS karena hanya menggunakan jaringan internet, tidak ada batasan karakter, memiliki beberapa fitur menarik misalnya mengirim gambar, audio, dan lain lain. Sedangkan kelemahan sosial media ialah menggunakan paket data internet dengan koneksi 3G, 4G atau WiFi (Rusni, 2017).

\section{KESIMPULAN DAN SARAN}

Short Message Service sebagai salah satu metode untuk meningkatkan kepatuhan ibu hamil dalam melakukan kunjungan $\mathrm{K} 4$ dan kemampuan ibu hamil dalam mendeteksi dini tanda bahaya 
kehamilan. Terdapat pengaruh Text Messaging Program terhadap kepatuhan antenatal care dan kemampuan deteksi dini tanda bahaya pada ibu hamil trimester III di wilayah Puskesmas Wedi, Klaten.

Diharapkan kepada Puskesmas dan tenaga kesehatan agar memakai metode Short Message Service sebagai salah satu metode untuk meningkatkan kemampuan deteksi dini tanda bahaya pada kehamilan. Bagi masyarakat diharapkan untuk selalu memanfaatkan teknologi informasi yang ada seperti Short Message Service, dan diharapkan selalu memeriksakan kehamilan secara teratur ke pelayanan kesehatan untuk mendeteksi faktor resiko atau tanda bahaya kehamilan, yang dapat berpengaruh pada kesehatan ibu dan bayi. Selain itu, diharapkan untuk peneliti selanjutnya untuk melakukan penelitian lanjutan mengenai Short Message Service untuk meningkatkan kunjungan pemeriksaan kehamilan dan kemampuan deteksi dini tanda bahaya pada ibu hamil trimester III.

\section{DAFTAR RUJUKAN}

Abdiansyah. (2009). Membangun SMSGateway untuk Pengisian Pulsa Elektronik. Jurnal Sistem Informasi, 1(2), 62-71. Retrieved from https://media.neliti.com/media/public ations/130075-ID-membangun-smsgateway-untuk-pengisian-pu.pdf

Andaruni, N. Q. R., Pamungkas, C. E., \& Lestari, C. I. (2017). Gambaran Tingkat Pengetahuan Ibu Hamil Tentang Tanda Tanda Bahaya Kehamilan Trimester I Di Puskesmas Karang Pule. Midwifery Journal, 2(2), 33-36.

Ardillah, S., Sanusi, S. R., \& Fitria, M.
(2015). Hubungan Pengetahuan dan Sikap terhadap Tindakan Ibu Hamil tentang Deteksi Dini Tanda-Tanda Bahaya Kehamilan di Puskesmas Medan Deli. Jurnal Gizi,Kesehatan Reproduksi, Dan Epidemiologi, 1. Retrieved from http://garuda.ristekdikti.go.id/docum ents/detail/322070

Cormick, G., Kim, N. A., Rodgers, A., Gibbons, L., Buekens, P. M., Belizán, J. M., \& Althabe, F. (2012). Interest of pregnant women in the use of SMS ( short message service ) text messages for the improvement of perinatal and postnatal care, 1-7. https://doi.org/10.1186/1742-4755-99

Elhaeart, B., Kundre, R., \& Lolong, J. (2017). Hubungan Tingkat Pendidikan, Pekerjaan, Status Ekonomi dengan Paritas di Puskesmas Bahu Manado. E-Journal Keperawatan, 5. Retrieved from https://media.neliti.com/media/public ations/110831-ID-hubungan-tingkatpendidikan-pekerjaan-st.pdf

Ermalena. (2017). Indikator Kesehatan SDGs di Indonesia. Retrieved from http://ictoh-tcscindonesia.com/wpcontent/uploads/2017/05/Dra.Ermalena-Indikator-Kesehatan-SdgsDi-Indonesia.pdf

Galuh, R., Indu, A., Sulistyono, A. (2015). Analisis Faktor yang Berpengaruh terhadap Kemampuan Ibu Hamil dalam Melakukan Deteksi Dini Risiko Perdarahan Pasca Persalinan dan Preeklamsia, 23(2), 49-53. 
Herlina, S. (2018). Evaluasi Hasil Penerapan Model Sms Gateway Dalam Promosi Kesehatan Tentang Bahaya Komplikasi Selama Kehamilan, 68-76.

Herlina, S., Sanjaya, G. Y., \& Emilia, O. (2013). Keefektifan SMS Reminder Sebagai Media Promosi Kesehatan Ibu Hamil di Daerah Terpencil. Snimed, (November), 31-38.

Hidayat, A. A. A. (2010). Metode Penelitian Kebidanan \& Teknik Analisis Data. Jakarta: Salemba Medika.

Kementerian Kesehatan Republik Indonesia. (2016). Buku Kesehatan Ibu dan Anak. Jakarta: Kemenkes RI. Kurnia, R. D., \& Ibrahim, A. (2015).

Pengembangan Model Sistem Informasi Monitoring Mahasiswa Berbasis Web dan SMS Gateway ( Studi Kasus: Jurusan Sistem Informasi Fasilkom Unsri ), 1-8. Retrieved from

https://repository.unsri.ac.id/6938/1/J urnal_Rizka_dan_Ali.pdf

Kusfriyadi, M. K., Hadi, H., \& Fuad, A. (2012). Pendidikan Gizi dan Pesan Gizi melalui Short Message Service terhadap Pengetahuan, Perilaku , dan Kepatuhan Ibu Hamil Minum Tablet Besi. Jurnal Gizi Klinik Indonesia, 9(2), 87-96. Retrieved from https://jurnal.ugm.ac.id/jgki/article/vi ew/15385/10320

Lestari, D. D. (2015). Reminder Terhadap Kepatuhan Ibu Hamil Dalam Mengkonsumsi Tablet Besi Di Wilayah Kerja. Pengaruh Pendidikan
Kesehatan Dan Sms Reminder Terhadap Kepatuhan Ibu Hamil Dalam Mengkonsumsi Tablet Besi Di Wilayah Kerja Puskesmas Pisangan Tahun 2015, 1-22. Retrieved from http://repository.uinjkt.ac.id/dspace/b itstream/123456789/28936/3/deti dwi lestari - fkik.pdf

Pattipeilohy, M. Y. (2018). Faktor Faktor yang mempengaruhi Perilaku Ibu terhadap Ketepatan Kunjungan Antenatal Care di Puskesmas Rekas Kabupaten Manggarai Barat Nusa Tenggara Timur Tahun 2017. Retrieved from http://eprints.poltekkesjogja.ac.id/17 21/1/skripsi full.pdf

Rachmawati, A. I., Puspitasari, R. D., \& Cania, E. (2017). Faktor-faktor yang Memengaruhi Kunjungan Antenatal Care ( ANC ) Ibu Hamil. Majority, 7(November), 72-76. https://doi.org/10.1002/2013WR0152 33

Rusni, A. (2017). Penggunaan Media Online Whatsapp dalam Aktivitas Komunitas One Day One Juz (ODOJ) dalam Menngkatkan Minat Tilawah ODOJER di Kota Pekanbaru, 2(1), 1-15. Retrieved from

https://media.neliti.com/media/public ations/188850-ID-penggunaanmedia-online-whatsapp-dalam-a.pdf

Sugiyono, P. D. (2016). Metode Penelitian Kuantitatif, Kualitatif, dan $R \& D$. Bandung: Alfabeta.

Ummah, D. A., \& Kostania, G. (2019). Penggunaan Text Messaging 
Program untuk Meningkatkan Kemampuan Ibu Hamil dalam Deteksi Dini Tanda Bahaya Kehamilan. Jurnal Ilmiah Bidan, IV, 19-24. Retrieved from ejournal.ibi.or.id

Wahyuni, Z. (2017). Pengaruh layanan pesan singkat terhadap pengetahuan dan intensi menyusui di kabupaten, 33, 261-266.

Walyani, E. S. (2015). Asuhan Kebidanan pada Kehamilan (I). Yogyakarta: Pustaka Baru Press. 